\title{
PELATIHAN PEMBUATAN JAMU INSTAN SEBAGAI DIVERSIFIKASI PRODUK PENGRAJIN JAMU DI KAMPUNG PEJABAT KELURAHAN LOKTABAT SELATAN BANJARBARU
}

\author{
Herningtyas Nautika Lingga ${ }^{1)}$, Fadlilaturrahmah ${ }^{2)}$, Eko Susilowati $^{3)}$ \\ ${ }^{122) 3}$ Universitas Lambung Mangkurat Banjarbaru, Kalimantan Selatan \\ Email : ${ }^{1)}$ herningtyas.nl@gmail.com \\ 2)Fadlilaturrahmah@ulm.ac.id \\ 3)Titisekos@gmail.com
}

\begin{abstract}
ABSTRAK
Kelurahan Loktabat Selatan merupakan daerah yang terkenal dengan penjual jamu gendong. Persentase pertumbuhan jamu dari tahun ke tahun meningkat dan berada di atas rata-rata pertumbuhan obat modern. Beberapa alasan yang mendasari pemilihan jamu sebagai alternatif pengobatan diantaranya adalah diyakini lebih aman dan minim efek samping. Tujuan dari pengabdian masyarakat ini adalah untuk meningkatkan pendapatan pengrajin jamu di kelurahan Loktabat Selatan. Pentingnya pengabdian masyarakat ini karena pada awalnya pengrajin jamu hanya menjual jamu segar (jamu gendong) yang nilai jual relatif rendah. Oleh karena itu, perlu dilakukan pelatihan pembuatan jamu instan sebagai diversifikasi produk pengrajin jamu, Pelaksanaan pengabdian diawali dengan sosialisasi dan penyuluhan tentang jamu instan, kemudian dilakukan praktek pembuatan jamu instan. Hasil yang diperoleh dari pengabdian masyarakat adalah pengrajin jamu mampu memproduksi jamu instan secara mandiri sebagai diversifikasi produk dan diharapkan dapat meningkatkan pendapatan.
\end{abstract}

Kata kunci: Pelatihan, Jamu Instan, Diversifikasi Produk, Kampung Pejabat

\section{PENDAHULUAN}

Industri jamu merupakan salah satu industri yang paling tua di Indonesia serta tumbuh dan berkembang dari akar budaya asli Indonesia. Tidak hanya itu, industri jamu juga memiliki struktur industri yang cukup kuat karena ditopang oleh ketersediaan sumber bahan baku berupa rempah-rempah, tanaman obat dan sumber plasma nutfah lainnya (Menperin, 2014). Kelurahan Loktabat Selatan, Kecamatan Banjarbaru Selatan merupakan daerah yang terkenal dengan penjual jamu gendong untuk kawasan Kalimantan Selatan. Saat ini 70\% masyarakat desa Loktabat bermata pencaharian sebagai penjual jamu gendong. Persentase pertumbuhanan jamu dari tahun ke tahun meningkat terus dan berada di atas ratarata pertumbuhan obat modern. Beberapa alasan yang mendasari pemilihan jamu sebagai alternatif pengobatan diantaranya adalah diyakini lebih aman. Tradisi minum jamu membuat konsumen lebih "cocok" dengan obat herbal ketimbang obat modern. Selain itu bahan baku obat herbal melimpah, Kalimantan Selatan merupakan salah satu daerah yang memiliki kekhasan tumbuhan yang berpotensi sebagai obat.

Dengan demikian sumber daya alam berupa rimpang dan sumber daya manusia masyarakat Loktabat secara bersinergi mampu mengoptimalkan hasil tentunya dengan peningkatan pendapatan. Pencapaian hasil tersebut dibutuhkan usaha yang kuat dari penduduk setempat untuk memanfaatkan peluang usaha pemanfaatan obat tradisional berkhasiat dengan diversifikasi Jamu kemasan (jamu instan) dengan berdasar pada CPOTB yang ditetapkan oleh menteri kesehatan dan Balai Besar Obat dan Makanan (BPOM), sehingga dalam penggunaannya lebih praktis dan efisien. Dengan demikian masyarakat Loktabat diharapkan dapat memanfaatkan peluang usaha tersebut untuk meningkatkan 
pendapatan mereka baik secara personal serta pendapatan daerah jika usaha yang dikembangkan berhasil dengan sukses sejalan dengan program pemerintah berbasis pada ekonomi kreatif kerakyatan.

\section{METODE PELAKSANAAN}

\section{Khalayak Sasaran}

Khalayak sasaran dalam kegiatan pengabdian masyarakat ini adalah pengrajin jamu di kampung pejabat kelurahan Loktabat Selatan, Banjarbaru, Kalimantan Selatan.

\section{Metode, Alat dan Baban yang Digunakan}

Metode pelaksanaan kegiatan pengabdian masyarakat dilakukan dengan ceramah dan peragaan atau praktek pembuatan jamu instan. Alat yang digunakan yaitu ayakan, wajan, kompor, blender, pisau, baskom, dan plastik kemasan. Bahan yang digunakan adalah air, kunyit, gula pasir, jeruk nipis, dan kayu manis.

\section{HASIL KEGIATAN}

Kesiapan pengusaha jamu tradisional menghadapi era Masyarakat Ekonomi Asean (MEA), maka mau tidak mau obat tradisional kita dianggap sudah mampu bersaing. Perusahaan multinasional ataupun PMDN seperti dianggap sudah bagus dan sudah mampu bersaing. Namun permasalahannya adalah perusahaan kecil obat tradisional (UKOT) masih terkendala keterbatasan sarana maupun SDM untuk membuat produk bigh quality dan kompetitif. Melihat kondisi tersebut, maka diperlukan suatu terobosan untuk meningkatkan sustainabilitas UKOT salah satunya adalah inovasi teknologi dalam produk obat tradisional. Pengembangan inovasi jamu dalam kemasan berawal dari ide pengembangan dan penggunaan produk non kimiawi yang saat ini lebih diminati masyarakat karena rendah efek samping.
Tren di masyarakat yang menjalani kehidupan "back to nature" menjadi suatu penciptaan pangsa pasar yang strategis dalam pemasaran produk jamu dalam kemasan yang berkualitas. Sebagian besar produk yang dihasilkan oleh pengrajin saat ini masih di pasarkan secara keliling berupa jamu gendong, sehingga nilai tambah dari produk tersebut masih kecil, dengan kegiatan Program Kemitraan Masyarakat (PKM) dapat menambah diversifikasi produk melalui jamu kemasan (jamu instan) yang dapat dipasarkan secara luas.

Kegiatan pengabdian masyarakat dilaksanakan pada hari Minggu, 26 Agustus 2018 pada pukul 14.00 - 18.00 WITA di Kampung Pejabat kelurahan Loktabat Selatan Banjarbaru. Dalam pelaksanaannya, tim utama kegiatan ini terdiri atas 3 orang dosen dan dibantu oleh 3 orang mahasiswa S1 Farmasi FMIPA Universitas Lambung Mangkurat. Kegiatan dilakukan dengan metode ceramah dan peragaan atau praktek secara langsung pembuatan jamu instan. Kegiatan diawali dengan penjelasan tentang alat dan bahan yang diperlukan dalam pembuatan jamu instan, disertai takaran masing-masing bahan. Selain itu, pengrajin jamu juga diberikan penjelasan terkait higienitas dalam hal pembuatan jamu. Kemudian dilanjutkan dengan peragaan atau praktek pembuatan jamu instan yang dibantu oleh mahasiswa. Pada saat praktek dilakukan, beberapa orang pengrajin jamu langsung dilibatkan. Agar pengrajin jamu lebih memahami langkah-langkah pembuatan jamu instan.

Untuk membuat jamu instan, terlebih dahulu bahan baku (misalnya; kunyit) dibersihkan terlebih dahulu dan diparut atau diblender. Hasil parutan diberi air yang kemudian diperas untuk mendapatkan sarinya. Hasil perasan dicampurkan dengan gula pasir dan kayu manis untuk selanjutnya dimasak dengan menggunakan api kecil sampai terbentuk serbuk. Proses pembuatan serbuk jamu dapat dilihat pada gambar 1. Serbuk jamu yang sudah jadi selanjutnya diayak untuk 
mendapatkan serbuk jamu yang halus (gambar 2) dan siap dikemas. Contoh serbuk jamu yang sudah dikemas (diversifikasi produk jamu instan) dapat dilihat pada gambar 3 .

Pada saat kegiatan, bahan baku yang digunakan sebagai contoh adalah kunyit. Kunyit (Curcuma domestica Val.) merupakan salah satu bahan baku jamu yang memiliki kandungan utama berupa kurkumin memiliki efek sebagai antiinflamasi dan antioksidan yang sangat tinggi. Selain itu, minyak atsiri pada kunyit mampu mengurangi gerakan usus yang kuat sehingga dapat digunakan sebagai antidiare. Manfaat lain dari kunyit adalah sebagai antikoagulan, obat malaria, mengobati keseleo, memar dan rematik serta bersifat antihepatotoksik (CCRC, 2014). Banyaknya manfaat yang dimiliki oleh kunyit membuat jamu berbahan dasar kunyit menjadi salah satu yang paling banyak dicari oleh konsumen berdasarkan pengakuan para pengrajin jamu.

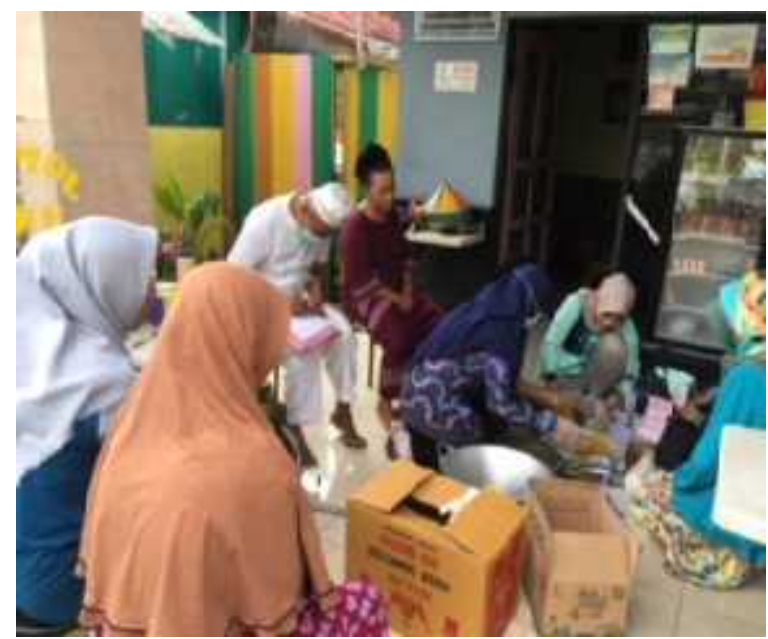

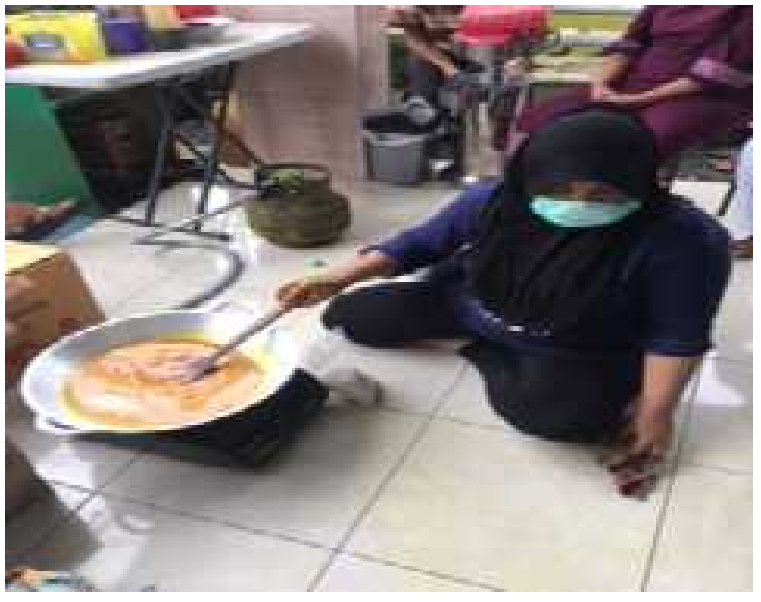

Gambar 1. Proses pembuatan jamu instan

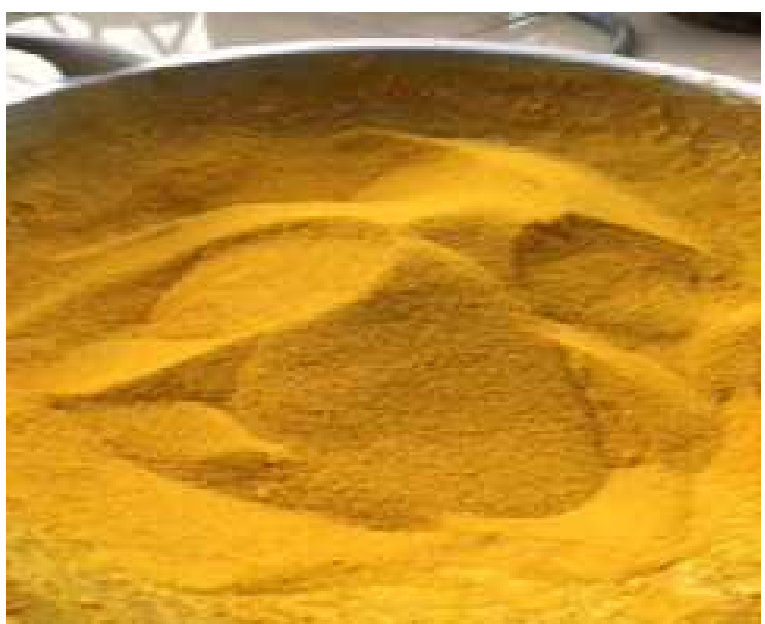

Gambar 2. Serbuk jamu

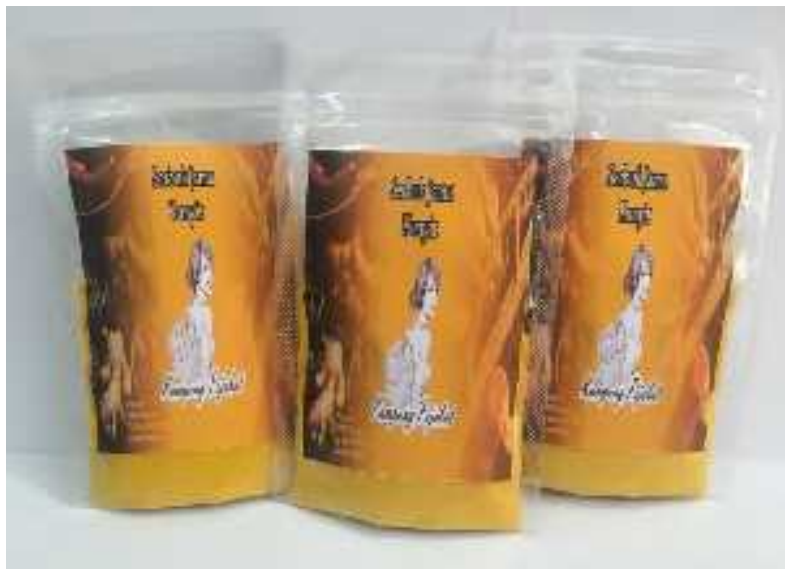

Gambar 3. Jamu Instan kemasan

Hasil dari kegiatan pelatihan adalah mitra (pengrajin jamu) memiliki pandangan cara meningkatkan pendapatan melalui diversifikasi 
produk jamu (jamu instan), mitra memiliki pendapatan tambahan disamping menjual jamu segar, mitra memiliki kemampuan dalam memproduksi jamu instan secara mandiri dan memasarkannya sebagai salah satu unggulan produk dari kampung pejabat.

\section{KESIMPULAN}

Pelatihan dan praktek pembuatan jamu instan membuat para pengrajin jamu mampu memproduksi jamu instan secara mandiri sebagai diversifikasi produk dan diharapkan dapat meningkatkan pendapatan para pengrajin jamu.

\section{DAFTAR PUSTAKA}

CCRC, 2014, Ensiklopedia Tanaman Antikanker: Kunyit (Curcuma longa Linn.), bttp:/ / ccrc.farmasi.ugm.ac.id/?page_id $=345 \#$, diakses tanggal 3 September 2018.

Kementerian Perindustrian, 2014, Kosmetika dan Herbal Menghadapi MEA 2015, Jakarta. 